\title{
Comparative Study of CdS Nano Films Deposited by Chemical Bath and Close Spaced Sublimation Techniques
}

\author{
Zamran Rabeel ${ }^{1}$, Murrawat Abbas ${ }^{2}$, Maryam Basit ${ }^{1}$, Nazar Abbas Shah ${ }^{3}$, Iqbal Ahmad ${ }^{4}$ and \\ Muhammad Sajjad Ul Hassan ${ }^{1}$ \\ ${ }^{1}$ Lecturer Punjab Higher Education Department Lahore \\ ${ }^{2}$ Federal Urdu University of Arts \& Sciences Islamabad, Pakistan \\ ${ }^{3}$ Department of Physics, Thin Film Technology Research Laboratory, COMSATS Institute of Information \\ Technology, Islamabad, Pakistan \\ ${ }^{4}$ Lecturer ,Department of Chemistry, Allama Iqbal Open University, Islamabad, Pakistan \\ Email: nazar_abbas@comsats.edu.pk
}

\begin{abstract}
Thin films of Cadmium Sulfide (CdS) are deposited on microscope glass slides by two techniques, chemical bath deposition (CBD) and close spaced sublimation (CSS). Cadmium Sulfide thin films fabricated by both procedures are characterized by spectrophotometer, scanning electron microscopy (SEM) and X-ray diffraction (XRD). Optical analysis of CdS thin films shows changes in transmittance, refractive Index and energy band gap by using two different techniques. XRD and SEM results show CdS thin film samples with better crystalline structure for close spaced sublimation technique and grain size is also found different for these two methods. CdS thin films fabricated by any of these two methods are good window layers with small thickness and suitable for CdTe/CdS/ITO based solar cells.
\end{abstract}

Keywords: Cadmium sulfide, close spaced sublimation, chemical bath deposition morphological, optical, structural study.

\section{Introduction}

A II-VI semiconductor compound Cadmium Sulfide (CdS) has much importance because of its so many applications in several heterojunction photovoltaic thin film devices of $\mathrm{CdTe}$, copper indium gallium diselenide $\left(\mathrm{Cu}\left(\mathrm{In}_{\mathrm{x}} \mathrm{Ga}_{1-\mathrm{x}}\right) \mathrm{Se}_{2}\right)$, or copper Indium Gallium sulfide (CIGS) and solar cells. Many other devices in the fields of electronics, optical and infrared are also fabricated by using CdS [1-3]. The CdS is a suitable $\mathrm{n}$-type material, which can be fabricated by a variety of fabrication techniques like sol gel technique [4], close spaced sublimation (CSS), chemical bath deposition (CBD), thermal evaporation, chemical vapor deposition, molecular beam epitaxy and spray pyrolysis. Each and every deposition process provides different optical, structural, electrical and morphological properties [5-10].

First solar company has reported CdS deposited by high rate vapor transport deposition (HRVTD). $\mathrm{CdS}$ is called window layer due to its higher rate of light transmission [11-14]. CdS thin films are very suitable for so many other semiconductor devices and radiation detectors. CdS thin films with wide band gap are highly used for photovoltaic devices. Since CdS is used as window layer in solar cell so it should be fabricated very thin, high amount of light should pass through CdS and be absorbed in CdTe. The CdS thin film must be continuous to reduce the effect of short circuit in the cell. The CdS thin films deposited by CBD can fulfill these requirements. So the thickness of CdS has much importance for the high efficiency of solar cell [15-17]. CdS (CBD) thin films are grown by Cadmium Chloride, Ammonium Nitrate, and Potassium Hydroxide after heating to a specific temperature Thiourea added to start the fabrication process [18-20].

CBD is a very easy process for the fabrication of CdS thin films on ITO glass. For the fabrication of thin film solar cell, one needs a very thin film up to $(60-80) \mathrm{nm}$. It is a very suitable process especially for solar cell point of view. It is a process in which substrate is placed in a hot chemical solution stirring vigorously for specific time, positive and negative ions will reach and meet on the substrate and thin 
film is grown. The advantage of this technique is that neither vacuum nor very high temperature is required for $\mathrm{CBD}[5,21]$.

CdS thin films fabricated by the CSS are also another moderate temperature fabrication technique in a vacuum chamber. More than $20 \%$ efficiency has been achieved by using CdTe/CdS heterojunction thin film solar cell by this technique. CSS is moderate temperature procedure so it provides in some cases better results [22-23]. The CSS technique is one of the techniques that has produced encouraging results, [15] mainly because it is simple deposition apparatus, high transport efficiency and deposition can be done in low vacuum at moderate temperatures. There is minimum use of material in the CSS system as compared to other methods. As the substrate is close to the source materials in the CSS technique, roughness increases in the thin films and has high absorption, which makes it suitable material for solar cell applications. The CSS has a disadvantage that one cannot introduce thickness monitor.

In this research work optical, structural and surface properties of CdS thin films by both methods have been studied by XRD, SEM and UV-VIS-IR Spectrophotometer. The objective of this investigation is to study two different techniques CBD and CSS and compare the properties of very promising compound material CdS thin films for the solar cell applications. We found that CBD films were more transparent and thinner but CSS films were less transparent due to surface roughness.

\section{$2 \quad$ Experimental}

Thin films of CdS were deposited on microscope glass slides and ITO glass slides. Two fabrication procedures were used for CdS deposition for the first time in our lab. Firstly CdS thin films were fabricated by CBD technique. Fabrication of thin film for solar cells, we need a very thin film up to (60 -80) $\mathrm{nm}$. In this process substrate was placed in a hot chemical solution stirring vigorously for 10 to 30 minutes with magnetic stirring at $3 \mathrm{~Hz}$ at $75{ }^{\circ} \mathrm{C}$ by combining positive and negative ions on the substrate thin film. The advantage is that neither vacuum nor very high temperature is required for CBD. The chemical solutions of $(0.02 \mathrm{M})$ about $80 \mathrm{ml}$ solution of Cadmium Chloride $\left(\mathrm{CdCl}_{2}\right),(1.5 \mathrm{M})$ about $80 \mathrm{ml}$ solution of Ammonium Nitrate $\left(\mathrm{NH}_{4} \mathrm{NO}_{3}\right)$ and $(0.5 \mathrm{M})$ about $200 \mathrm{ml}$ solution of Potassium Hydroxide $(\mathrm{KOH})$ were made in a beaker. When temperature reached at $75^{\circ} \mathrm{C}$ thiourea of $(0.2 \mathrm{M})$ about $80 \mathrm{ml}$ solution was added to start fabrication. The films were fabricated with magnetic stirring of $3 \mathrm{~Hz}$ for 10-30 minutes at $75^{\circ} \mathrm{C}$. as described in [5].

CdS (CSS) fabrication was carried out in a vacuum chamber of approximately $4 \times 10^{-1} \mathrm{mbar}$. The CdS Sigma Aldrich powder $99.999 \%$ pure was used. Substrate temperature was maintained at $400{ }^{\circ} \mathrm{C}$ and source temperature was in between $(500-600)^{\circ} \mathrm{C}$. Source material was heated by $1000 \mathrm{~W}$ halogen lamp and substrate was heated by a $500 \mathrm{~W}$ halogen lamp. Time of deposition was about (3-5) minutes as shown in Fig.2. The fabricated film was collected after cooling.

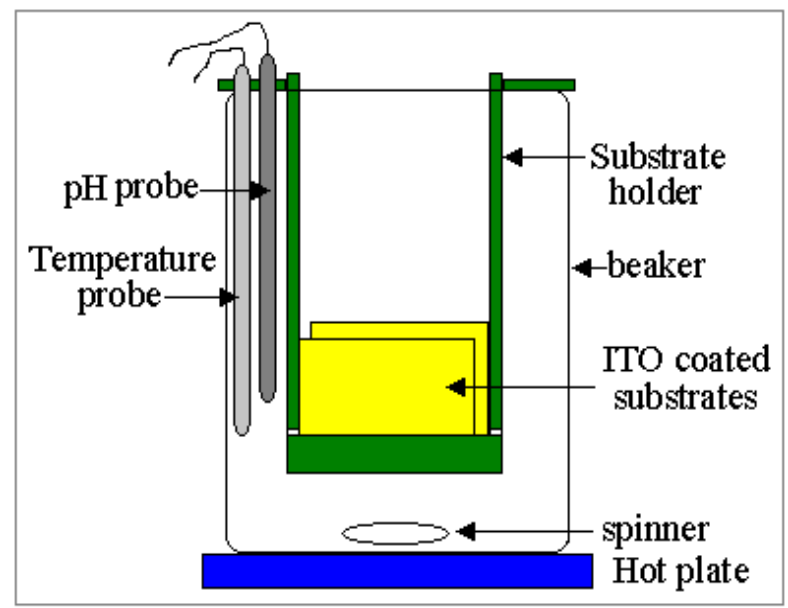

Figure 1. Schematic drawing of CBD set-up 


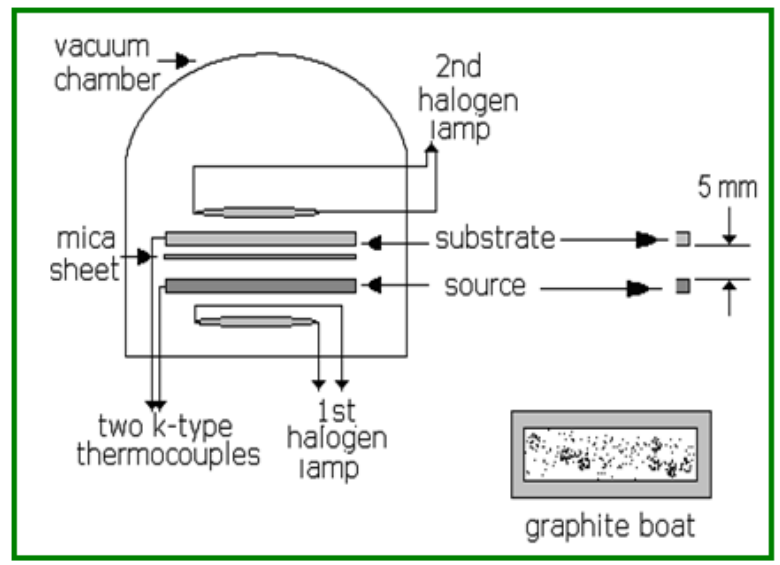

Figure 2. CSS arrangement designed at CIIT

\section{Comparative Analysis of Optical Properties of CdS Thin Films Deposited by Chemical Bath Deposition and Close Spaced Sublimation}

Spectrophotometer (UV-VIS-IR) was used to study optical properties of CdS (CBD) and CdS (CSS) thin films. The transmission for (CBD) films starts after $300 \mathrm{~nm}$ wavelength but in case of (CSS) transmission starts after $500 \mathrm{~nm}$ as shown in figure 4. So in CdS (CSS) blue portion of light was absorbed. Transmission increased especially above $550 \mathrm{~nm}$ wavelength region. In the region of 600 to 800 $\mathrm{nm}$ the transmission was more than $70 \%$ for both (CBD) and (CSS), so light transmission through (CBD) films was higher than (CSS) as shown in figure 4. This characteristic showed that CdS was a good window layer for the thin film solar cells of many kinds fabricated by both of the techniques. The Swanepoel model provided calculations about thickness and refractive index. Energy values were calculated by plotting a graph between energy and $(\alpha h v)^{2}$. Formula for refractive index $(n)$ is given in equation 1 and 2 .

$$
\mathrm{n}=\frac{\mathrm{N}^{2}+\sqrt{\left(\mathrm{N}^{2}-4 \mathrm{~S}^{2}\right)}}{2}
$$

"N" represents the number of oscillations and can be calculated as

$$
\mathrm{N}=1+\mathrm{S}^{2}+4 \mathrm{~S}\left(\frac{\mathrm{T}_{\mathrm{M}}-\mathrm{T}_{\mathrm{m}}}{\mathrm{T}_{\mathrm{M}} \mathrm{T}_{\mathrm{m}}}\right)
$$

$\mathrm{S}$ is the substrate refractive index, now thickness " $\mathrm{d}$ " can be calculated as

$$
d=\frac{1}{4 n}\left[\frac{\lambda_{M} \lambda_{m}}{\lambda_{M} \lambda}\right]
$$

from the transmission curves. The energy gap of the material can be calculated with the help of the following equation [24]

$$
\alpha h v=A\left(h v-E_{g}\right)^{N / 2}
$$

where alpha $(\alpha)$ is absorbtion coefficient, $\mathrm{A}$ is a constant, hu is the photon energy, $\mathrm{E}$ is the energy gap and $\mathrm{N}$ depends on the nature of transition. The absorption co-efficient can be calculatêd as

$$
\alpha=\frac{1}{d} \ln \left[\frac{1}{T}\right]
$$

where $d$ is the thickness and $T$ is the transmittance, $\lambda_{m}$ is the minima and $\lambda_{M}$ is the maxima value of the wavelength taken from the transmission spectrum [8]. 


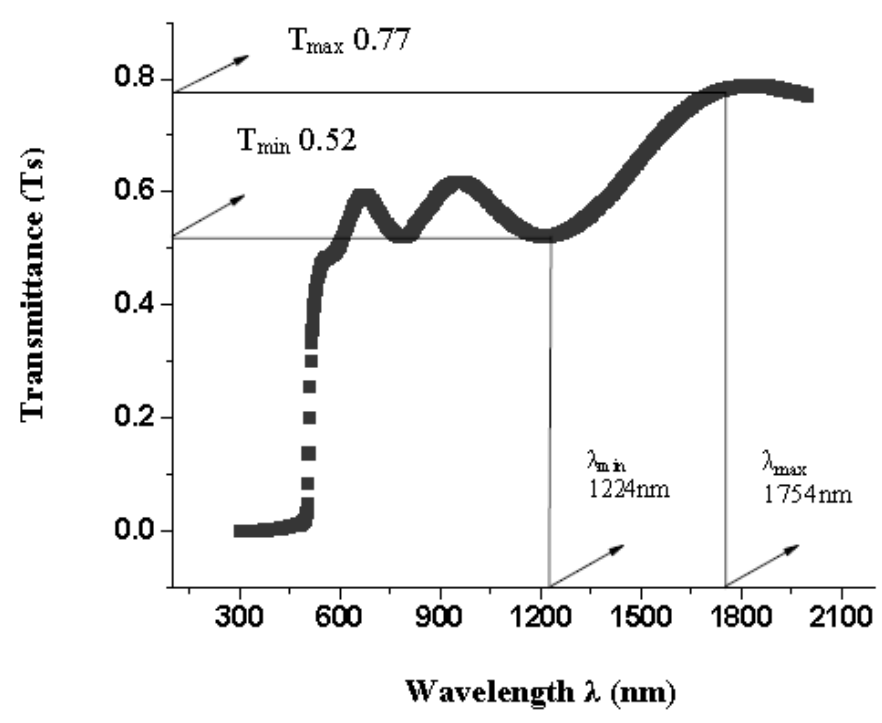

Figure 3. Transmittance (T) curve of as-deposited CdS sample
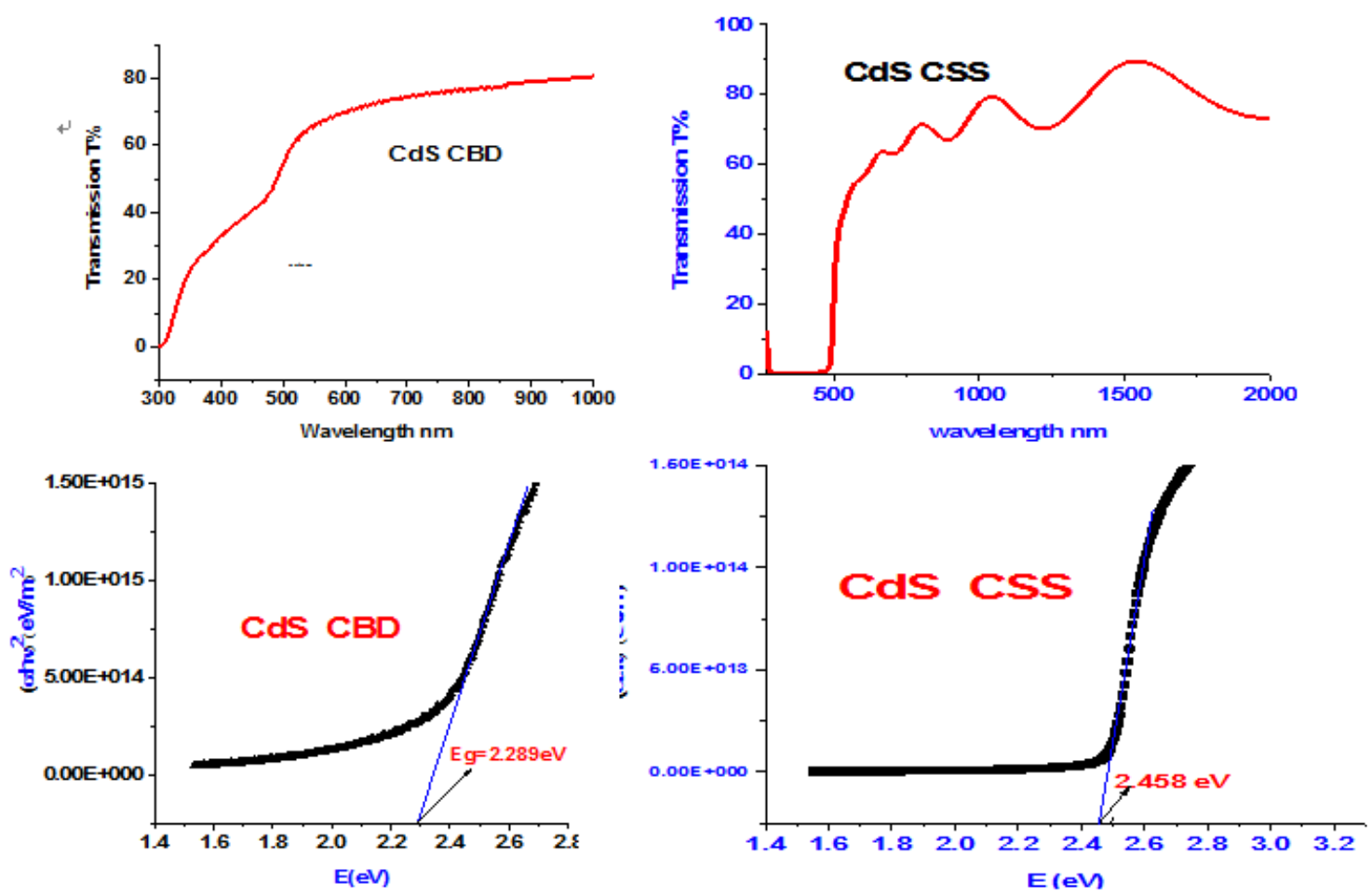

Figure 4. CdS Transmission and Energy band spectra for both (CBD) \& (CSS)

Energy band gap behavior with respect to thickness was almost same for both CBD and CSS. The energy band gap was $2.32 \mathrm{eV}$ of CBD for thickness of $42 \mathrm{~nm}$. It was $2.39 \mathrm{eV}$ for $257 \mathrm{~nm}$ thickness samples.

Similarly for CSS, the band gap was increasing with increase of thickness but it then decreased for higher thickness. Band gap was $2.30 \mathrm{eV}$ for $574 \mathrm{~nm}$ thickness which was increased to $2.46 \mathrm{eV}$ for 1184 $\mathrm{nm}$ thickness but then it decreased to $2.37 \mathrm{eV}$ for $1800 \mathrm{~nm}$ thickness. 


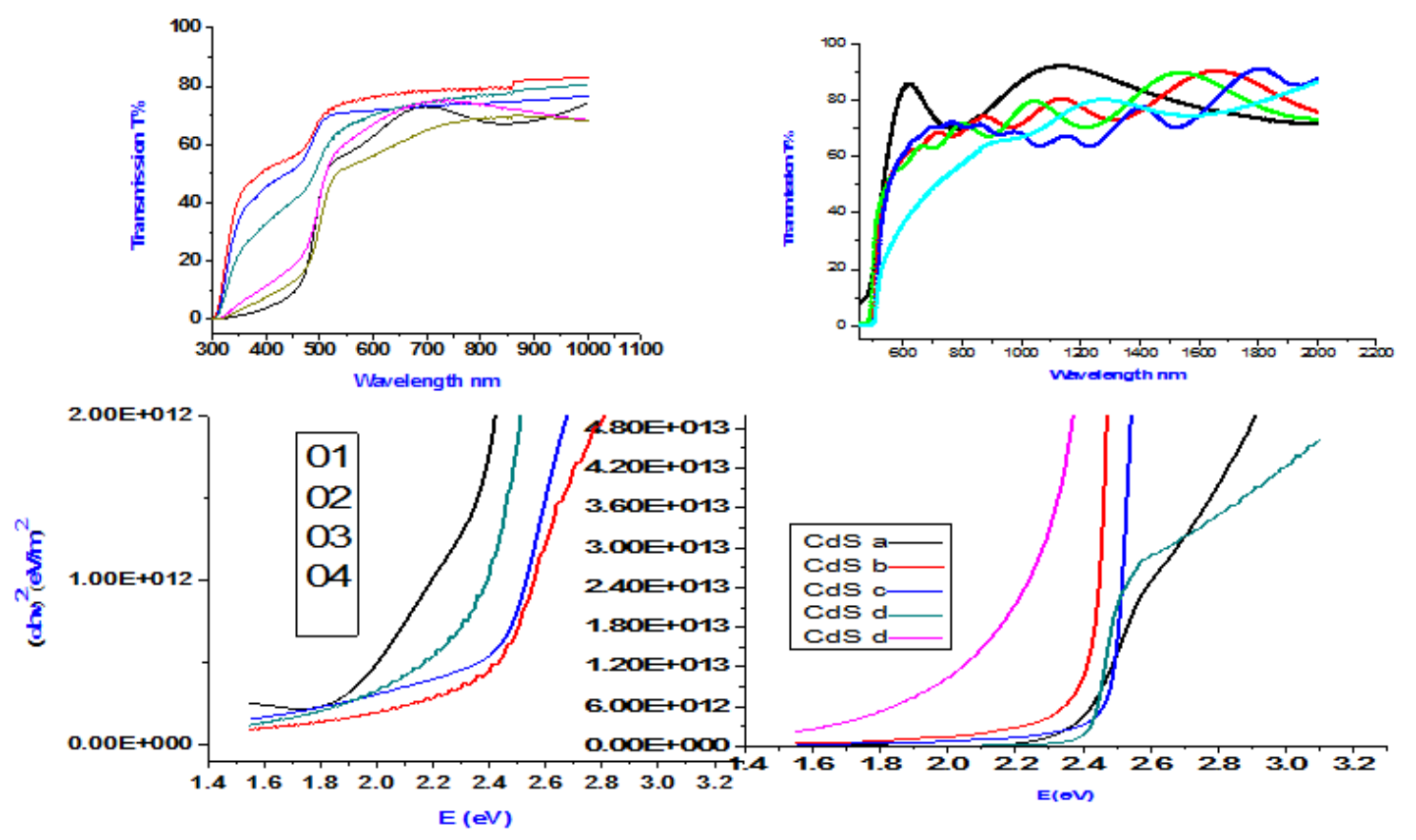

Figure 5. Combined Transmission Spectra and Energy band gaps of CdS CBD

Table 1. CBD thickness \& band gap

\begin{tabular}{llll}
\hline S.No CBD & Deposition Time $(\mathbf{m i n})$ & Thickness $(\mathbf{n m})$ & $\mathbf{E}_{\mathbf{g}}(\mathbf{e V})$ \\
\hline 1 & 5 & 42 & 2.32 \\
2 & 8 & 55 & 2.34 \\
3 & 10 & 60 & 2.29 \\
4 & 20 & 127 & 2.36 \\
5 & 40 & 257 & 2.39 \\
\hline
\end{tabular}

Table 2. CSS thickness \& band gap

\begin{tabular}{llll}
\hline S.No CSS & Deposition Time (min) & Thickness $(\mathbf{n m})$ & $\mathbf{E}_{\mathrm{g}}(\mathbf{e V})$ \\
\hline $\mathrm{A}$ & 4 & 574 & 2.30 \\
$\mathrm{~B}$ & 5 & 583 & 2.39 \\
$\mathrm{C}$ & 6 & 803 & 2.43 \\
$\mathrm{D}$ & 8 & 1184 & 2.46 \\
$\mathrm{E}$ & 10 & 1800 & 2.37 \\
\hline
\end{tabular}

\section{Structural Analysis of CdS (CBD) and CdS (CSS)}

Structural properties were studied by X-ray diffraction using CuK $\alpha$ radiations of $1.5418 \AA$. The data analysis provided lattice constant as $6.50 \AA$ for as deposited sample. The lattice parameter can be calculated by using the relation for only cubic structure.

$$
\mathrm{a}=\mathrm{d} \sqrt{\mathrm{h}^{2}+\mathrm{k}^{2}+\mathrm{l}^{2}}
$$

where $\mathrm{h}, \mathrm{k}, \mathrm{l}$ are Miller indices, for hexagonal structure formula for " $\mathrm{d}$ " is

$$
\frac{1}{\mathrm{~d}^{2}}=\frac{4}{3}\left(\frac{\mathrm{h}^{2}+\mathrm{hk}+\mathrm{k}^{2}}{\mathrm{a}^{2}}\right)+\frac{l^{2}}{c^{2}}
$$




$$
\text { Crystalline Size }=\frac{(0.9 \lambda)}{\operatorname{Cos}}
$$

where $\lambda$ is X-rays wavelength, 0.9 is a constant shape factor, $\beta$ is full width half maxima in radians, $\theta$ is Bragg's angle. [25] Peaks relating to CdS can be identified by using standard card JCPDS-00-041-1049. The d-spacing values were compared with standard values of ASTM cards to find the structure. It was observed in this experimental work that CdS thin films had a mixed structure of $\mathrm{H}(002)$ and $\mathrm{C}$ (111) for both techniques. So CdS has a polycrystalline behavior [20-22].

The XRD spectra were taken scanning the values of $2 \theta$ from $20^{\circ}$ to $80^{\circ}$. In CdS (CSS) high energy planes were grown during the film growth due to high temperature but in CdS (CBD) recrystallization can be observed due to low temperature [21]. In most of the research papers CBD has dominant cubic structure [22-24] and CSS process has dominant hexagonal structure [15] but most of the times mixed structures were obtained [23]. In our research work for both CBD and CSS techniques first hexagonal strong peak was dominant. The size of grains was different for different fabrication techniques. This may be due to film thickness, temperature or different nucleation rate of $\mathrm{CdS}$ for different deposition methods [25]. Fig. 6 (a) and (b) showed the X-ray diffraction traces of CBD and CSS. The $2 \theta$ values for first peak for both CBD and CSS were in between (25-26.8) degree of angle.
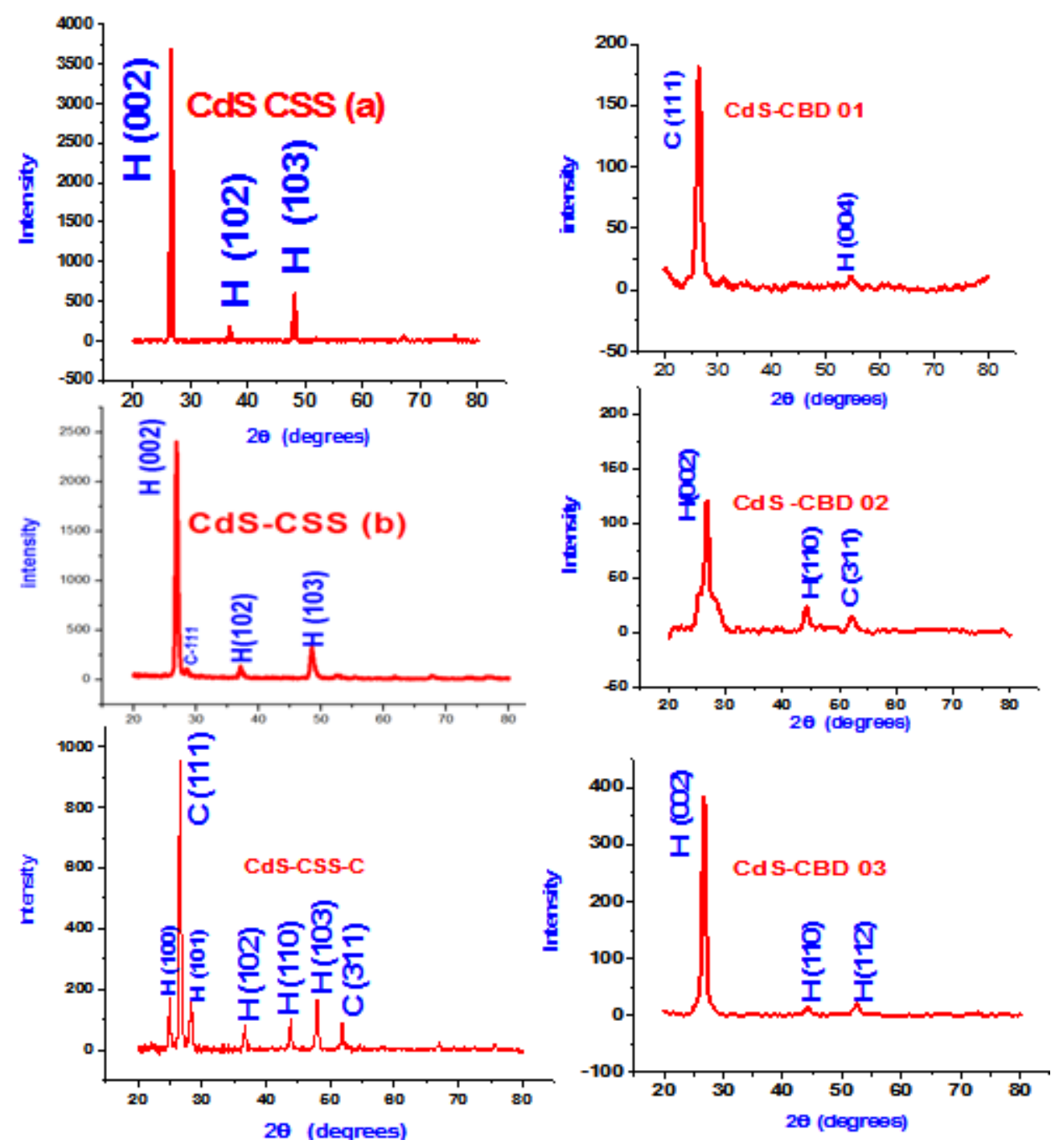

Figure 6. (a) XRD graphs by CSS; (b) XRD graphs by CBD 
Table 3. XRD data for CdS (CBD)

\begin{tabular}{|c|c|c|c|c|c|c|}
\hline $\begin{array}{c}\text { S.No } \\
\text { (CBD) }\end{array}$ & $2 \theta$ & FWHM & Crystalline size $(\AA)$ & Crystal System & \multicolumn{2}{|c|}{ Lattice parameter } \\
\hline $\operatorname{CdS}(1)$ & 26.49 & 0.47 & 173.02 & Cubic and Hexagonal & $\begin{array}{l}\text { [111] Cubic } \\
\text { [004] Hexagonal }\end{array}$ & $\begin{array}{l}\mathrm{a}_{\mathrm{o}}=5.82 \AA \\
\mathrm{a}=4.14 \AA \\
\mathrm{c}=6.7 \AA\end{array}$ \\
\hline $\mathrm{CdS}(2)$ & 25.19 & 0.39 & 207.07 & Cubic and Hexagonal & $\begin{array}{l}{[311] \text { Cubic }} \\
\mathrm{H}[002,110] \\
\mathrm{c}=6.7 \AA\end{array}$ & $\begin{array}{l}\mathrm{a}_{\mathrm{o}}=6.12 \AA \\
\mathrm{a}=4.14 \AA\end{array}$ \\
\hline $\mathrm{CdS}(3)$ & 26.74 & 0.15 & 519.43 & Hexagonal & $\begin{array}{l}{[002,110,112] \text { All }} \\
a=4.14 \AA \quad c=\end{array}$ & $\begin{array}{l}\text { Hexagonal } \\
=6.7 \AA\end{array}$ \\
\hline
\end{tabular}

Table 4. XRD traces of CdS (CSS) as deposited samples

\begin{tabular}{|c|c|c|c|c|c|}
\hline $\begin{array}{l}\text { S.No } \\
(\mathrm{CSS})\end{array}$ & $2 \theta$ & FWHM & $\begin{array}{l}\text { Crystalline size } \\
(\AA)\end{array}$ & Crystal System & Lattice parameter \\
\hline $\begin{array}{l}\text { CdS } \\
\text { (a) }\end{array}$ & 26.71 & 0.3542 & 230 & Hexagonal & $\begin{array}{l}{[002,102,103] \text { All Hexagonal } \mathrm{a}=4.14 \AA} \\
\mathrm{c}=6.72 \AA\end{array}$ \\
\hline $\begin{array}{l}\text { CdS } \\
\text { (b) }\end{array}$ & 26.82 & 0.4330 & 188 & Hexagonal & $\begin{array}{l}{[002,102,103] \text { All Hexagonal }} \\
\mathrm{a}=4.14 \AA \quad \mathrm{c}=6.72 \AA[220] \text { Cubic }\end{array}$ \\
\hline $\begin{array}{l}\mathrm{CdS} \\
\text { (c) }\end{array}$ & 25.0204 & 0.2755 & 295 & $\begin{array}{l}\text { Cubic and } \\
\text { Hexagonal }\end{array}$ & $\begin{array}{ll}\text { [111] Cubic } & \mathrm{a}_{\mathrm{o}}=6.16 \AA \\
{[101,102] \text { Hexagonal }} & \mathrm{a}=4.14 \AA \\
& \mathrm{c}=6.72 \AA\end{array}$ \\
\hline & & & & & $\begin{array}{l}\mathrm{a}=4.13 \AA \\
\mathrm{c}=6.71 \AA\end{array}$ \\
\hline
\end{tabular}

In CdS (CSS) strong and high peak was H(002) for two samples and it was $\mathrm{C}(111)$ for third sample. It was very difficult to elucidate for (c) sample as hexagonal or cubic structure, because difference in position of peak was very small upto $\left(0.021^{\circ}\right)$ as reported [26-27]. Height of peak/ intensity was 4000, 2500 , and 1000 counts at $2 \theta$ value of $(26.705,26.8218$ and 26.5638$)$ degree, other peaks were $\mathrm{H}(002)$, $\mathrm{H}(103)$ and $\mathrm{C}(220)$ which proved the polycrystalline behavior of CdS thin films. The height of peak/intensity for CdS (CBD) was only upto 200, 150 and 400, first strong peak was H(002) for two samples and $\mathrm{C}(111)$ for third sample at $2 \ominus$ value of $(26.49,25.19,26.74)$ degree of angle.

\section{$5 \quad$ SEM Analysis of CdS (CBD) and CdS (CSS)}

Surface morphology was studied by using Scanning Electron Microscopy (SEM). Grain size for CdS (CSS) was measured as (300-400) nm.
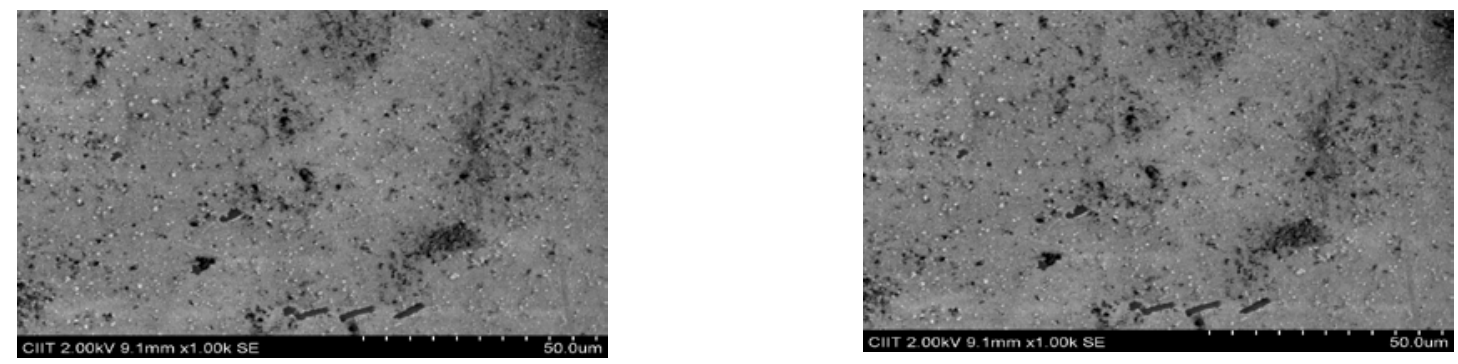

Figure 7. (a) CBD-CdS of $170 \mathrm{~nm}$ thickness; (b) CBD-CdS of $60 \mathrm{~nm}$ thickness 

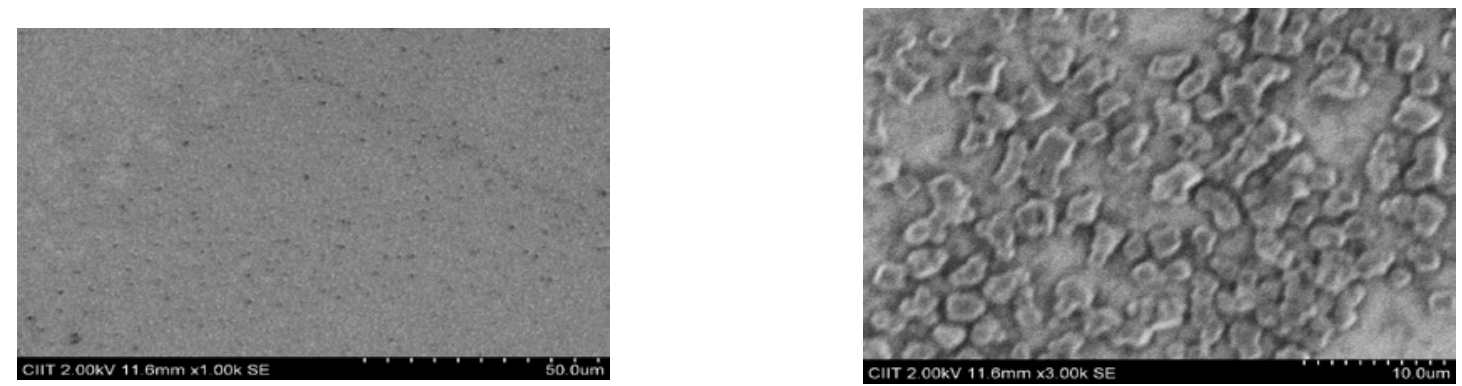

Figure 8. (a) CSS-CdS at source temperature $650{ }^{\circ} \mathrm{C}$ and (b) $\mathrm{CSS}-\mathrm{CdS}$ at $680^{\circ} \mathrm{C}$

Surface of CBD films was slightly non uniform but CdS (CSS) structure was fine with better Crystallinity. SEM analysis showed that CBD-CdS thin films grain size approximately was found to be (50-100) nm and CSS-CdS films grain size was approximately (200-300) nm. It was also observed that at high source temperature, grain size was bigger in the CSS technique. It is reported in the literature that even less crystalline and non uniform films of CBD process gave high efficiency as compared to CSS [5].

\section{Conclusion}

CdS thin films were fabricated on glass slides by CBD and CSS techniques successfully. XRD results showed that both fabrication methods gave mixed hexagonal and cubic structure. Size of grains in CSS was bigger than CBD. High peaks in CSS showed that it had better crystalline structure as compared to CBD. Films of CBD were more transparent and thinner but CSS films were less transparent due to surface roughness. Transmission in CBD started after $300 \mathrm{~nm}$ of light wavelength but for CSS light transmission started after $500 \mathrm{~nm}$. So CSS thin films absorbed blue portion of light more. Both fabrication methods produced more than $70 \%$ transmission of light in the visible spectrum. The band gap behavior as a function of thickness was same for both CBD and CSS. CdS thin films are more suitable materials as window layer in solar cell fabrications.

\section{References}

1. N.A.Shah, W.A.Adil, M.A.Atta "Characterization of II-VI Semiconductor thin films fabricated by Close Spaced Sublimation" J. Nanoscience and nanotechnology letters, (2009), pp (65-69).

2. M.Khaled, Abu El-Rub, S.R. Hahna, S. Tari and M.A.K.L. Dissanayakec, "Effects of CdCl heat treatment on the morphological and chemical properties of CdTe/CdS thin films solar cells" Applied Surface Science, (2012), pp (6142).

3. M.A.GREEN, K. EMERY, Y.HISHIKAWA, "Solar Cells Efficiency Tables (version 42)", Pro-gress in Photovoltaics: Research and Applications, (2013), 21 pp (827-837).

4. R. Reisfeld, "Nanosized semiconductor particles in glasses prepared by the sol-gel method: their optical properties and potential uses" Journal of Alloys and Compounds, (2002), 341 pp (1-12).

5. Y. A. Salazar, R. Patino, J. L. Pena, W. Cauich, and A.I. Oliva, "Physical Properties of CdS/ITO Thin Films Growth by CBD Technique with Substrate Oscillating Agitation” Brazilian Jr. Phy, (2006), 36 pp (1058-1061).

6. A. Ordaz-Flores, P. Bartolo-Perez, R.Castro-Rodrıguez, A.I. Oliva Revista Mexicana De Fisica, "Annealing effects on the mass diffusion of the CdS/ITO interface deposited by chemical bath deposition"J. REVISTA MEXICANA, (2005), 52 pp (15-19).

7. Q.Q. Liu, J.H. Shi, Z.Q. Li, D.W. Zhang, X.D. Li, Z Sun, L.Y. Zhang, "Morphological and stoichiometric study of CBD CdS films by varying ammonia concentration" J. Physics of Condensed Matter, (2010), 405 pp (43604365).

8. N. A. Shah, A. Nazir, "Physical properties and characterization of Ag doped CdS thin films" Journal of Alloys and Compounds, (2012), 512 pp (27-32). 
9. D.Bonnet, et al., "New results on the development of a thin film p-CdTe-nCdS heterojunction solar cell" In the proceedings of the 9th IEEE, Photovoltaic Specialists Conference, (1972), pp (129-132).

10. N.A.Shah, A. Ali, S. Hussain and A. Maqsood, "CdCl-treated CdTe thin films deposited by the close spaced sublimation technique" J. Coat. Technol. Res., (2010), 7 pp (105).

11. S. Linsi, B. Kavitha, M. Dhanam and B. Maheswari, "Analysis of Cu:CdS Thin Films of Three Different Copper Compositions" World Applied Sciences Journal, (2010), 10 pp (207-213).

12. N.A. Shah, A. Nawaz, A. Kanwal and W.A. Syed, "Comparative Study of Cadmium Sulfide Thin Films at Room and Low Temperatures Fabricated by Closed Space Sublimation Technique" World Applied Sciences Journal, (2013), 28(4) pp (548-553).

13. P.Sinha, "Life cycle materials and water management for CdTe photovoltaics" J.Solar Energy Materials \& Solar Cells, (2013), 119 pp (271-275).

14. M. Gloeckler, I. Sankin, Z. Zhao "CdTe Solar Cells at the Threshold to 20\%" IEEE Journal of Photovoltaic, (2013), 3 pp (1389-1393).

15. L. Rosa Cruz1, J. Antônio Sousa Fernandes1, C. Luiz Ferreira1, W. Anacleto Pinheiro,

"Microstructural and optical properties of CSS and CBD-CdS thin films for photovoltaic solar cells" Journal of REVISTAMATERIA, (2014), pp (228-234).

16. R. MENDOZA-PEREZ, G. SANTANA-RODRIGUEZ, J. SASTRE-HERNANDEZ, et al. "Effects of thiourea concentration on CdS thin films grown by chemical bath deposition for CdTe solar cells" Journal of Thin Solid Films, (2005), 480-481 pp (173-176).

17. H.R. MOUTINHO, D. ALBIN, Y. YAN, "Deposition and properties of CBD and CSS CdS thin films for solar cell application" Thin Solid Films, (2003), V 436, pp (175-180).

18. N. A. Adnan, N. A. Shah, "Effect of Ag doping on opto-electrical properties of CdS thin films for solar cell applications" Journal of Alloys and compounds, (2014), 609 pp (40-45).

19. M.D.G. Potter, M. Cousins, K. Durose and D.P. Halliday, "Effect of interdiffusion and impurities on thin film CdTe/CdS photovoltaic junctions" Journal of Materials Science: Materials in Electronics, (2000), 11 pp (525).

20. C.Y. Park, U. Kefayat, N. Vikram, T.Ghosh, W.C. Oh and K.Y.Cho "Preparation of novel CdSgraphene/TiO2 composites with high photocatalytic activity for methylene blue dye under visible light" Bulletin of Materials Science, (2013), 36 pp (869).

21. N.A. Shah, A. Ali and A. Maqsood "Preparation and Characterization of CdTe for Solar Cells, Detectors and Related Thin Film Materials" J.Electron. Mater, (2008), 37 pp (145).

22. J. SCHAFFNER, E. FELDMEIER, A. SWIRSCHUK, "Influence of substrate temperature, growth rate and TCO substrate on the properties of CSS deposited CdS thin films", Thin Solid Films, (2011), 519 pp. (7556-7559).

23. E.M. FELDMEIER, A. FUCHS, SCHAFFNER, "Comparison between the structural, morpho-logical and optical properties of CdS layers prepared by Close Space Sublimation and RF magnetron sputter-ing for CdTe solar cells" Thin Solid Films, (2011), 519 pp (7596-7599).

24. A.I.Oliva, R.Casto-Rodriguez, O. Solis-Canto, Victor Sosa, P.Quintana, J.L.Pena, "comparison of properties of CdS thin films grown by two techniques" Jr. applied surface science, (2003), pp (56-64).

25. P.M. Lisco, Kaminski, A.Abbas, K.Bass, J.W. Bowers, G. Claudio, M.Losurdo, J.M. Walls, "The structural properties of CdS deposited by chemical bath deposition and pulsed direct current magnetron sputtering" J. Thin Solid Films, (2015), 582 pp (323-327).

26. H. Moualkia, S. Hariech, M.S. Aida, Structural and optical properties of CdS thin films grown by chemical bath deposition" Thin Solid Films, (2009), 518 pp (1259-1262).

27. M.A. Islama, M.S. Hossainb,M.M.Aliyub, P. Chelvanathana, Q. Hudaa, M.R. Karimc, K. Sopiana, N. Amin, "Comparison of Structural and Optical Properties of CdS Thin Films Grown by CSVT, CBD and Sputtering Techniques" Energy Procedia, (2013), 33 pp (203-213). 